\title{
The Australian Constitution and the Aid/Watch Case
}

\author{
George Williams \\ University of New South Wales
}

\begin{abstract}
The Australian Constitution played a significant role in underpinning the result in the Aid/Watch Case. It was invoked by the majority to support their conclusion that a body can be a 'charitable institution' despite engaging in political activities. The use of the Constitution in this way came as a surprise. The case extended an existing constitutional principle relating to freedom of political communication from its electoral base into the protection of the political activities of non-government organisations. This may have future ramifications for those organisations in other areas, as well as further implications for the development of what it means to be a charity in Australia. This article examines the use of the Australian Constitution in the Aid/Watch Case. It explains how the High Court was able to invoke the Constitution in defining what it means to be a 'charitable institution'. It also examines the implications of that reasoning for the development of charitable law in Australia.
\end{abstract}

\section{Introduction}

The Australian Constitution played a significant role in underpinning the result in the Aid/Watch Case. ${ }^{1}$ It was invoked by the majority to support their conclusion that a body can be a 'charitable institution' despite engaging in political activities.

The use of the Constitution in this way came as a surprise. The case extended an existing constitutional principle relating to freedom of political communication from its electoral base into the protection of the political activities of non-government organisations. This may have future ramifications for those organisations in other areas, as well as further implications for the development of what it means to be a charity in Australia.

This article examines the use of the Australian Constitution in the Aid/Watch Case. It explains how the High Court was able to invoke the Constitution in defining what it means to be a 'charitable institution'. It also examines the implications of that reasoning for the development of charitable law in Australia.

\footnotetext{
${ }^{1}$ Aid/Watch Inc v Commission of Taxation (2010) 272 ALR 417. 


\section{Political activities and 'charitable institutions'}

In contrast to the modern practice of parliaments seeking to define key terms with often extraordinary precision, 'charitable institution' is not at all defined in Australia’s key tax laws, such as the Income Tax Assessment Act 1997 (Cth). The term is mentioned merely by way of indicating a type of entity that is entitled to significant tax concessions. This leaves the courts with the task of filling in what has proved to be an enormous gap in the law. They must determine the characteristics of a 'charitable institution', including questions such as whether such institutions can engage in political activities.

Current law on what is a 'charitable institution' can be traced back to the preamble to the English Parliament's 1601 Statute of Charitable Uses (also known as the Statute of Elizabeth). The 'modern' starting point for applying these words lies in the 1891 decision of Lord Macnaghten in the United Kingdom House of Lords in Commissioners for Special Purposes of Income Tax $v$ Pemsel. ${ }^{2}$ He classified charities into four divisions:

'Charity' in its legal sense comprises four principal divisions: trusts for the relief of poverty; trusts for the advancement of education; trusts for the advancement of religion; and trusts for other purposes beneficial to the community, not falling under any of the preceding heads.

Subsequent decisions in the United Kingdom have found that a body cannot fall into any of these categories if it engages in political activities. Hence, in the leading case of Bowman $v$ Secular Society $\mathrm{Ltd}^{3}$ in 1917, Lord Parker of Waddington in the House of Lords stated:

a trust for the attainment of political objects has always been held invalid, not because it is illegal, for every one is at liberty to advocate or promote by any lawful means a change in the law, but because the Court has no means of judging whether a proposed change in the law will or will not be for the public benefit, and therefore cannot say that a gift to secure the change is a charitable gift.

This decision has led to recognition in the United Kingdom that a body cannot be a charity if it has a 'political object', such as to promote change in the law or government policy. In 2006, for example, in Hanchett-Stamford v Attorney-General ${ }^{4}$, Lewison J recognised 'the fundamental principle that if one of the objects or purposes of an organisation is to change the law, it cannot be charitable’.

\footnotetext{
${ }^{2}$ [1891] AC 531 at 583.

3 [1917] AC 406 at 442.

${ }^{4}[2009]$ Ch 173 at $181-182$.
} 
At the time of the Aid/Watch Case, the Australian High Court had not yet determined whether to follow this British line of reasoning. As a matter of common law, or judge-made law, the matter was open for determination. It is also open to the High Court to apply Australian constitutional doctrine in reaching its decision.

Ultimately, a majority of the High Court decided not to follow the British line of reasoning stemming from Bowman. They held that a body can be a 'charitable institution' and still engage in political activities. In large part, this rested upon their development of the common law. However, the decision also relied upon principles derived from the Australian Constitution. Indeed, in deciding not to follow the United Kingdom path, the majority stated:

The starting point must be that the remarks of Lord Parker in Bowman were not directed to the Australian system of government established and maintained by the Constitution itself. That circumstance, as explained in what follows, provides a significant consideration in deciding the content of the common law of Australia respecting trusts for 'political objects'.

Australia's Constitution does not contain a Bill of Rights ${ }^{6}$, nor even any express recognition of freedom of speech. However, beginning in 1992 at the time of the Mason Court with the decisions in Nationwide News Pty Ltd $v$ Wills $^{7}$ and Australian Capital Television Pty Ltd $v$ Commonwealth, ${ }^{8}$ the High Court has recognised that the Constitution implies that Australian parliaments cannot pass laws that unduly interfere with the ability of Australians to communicate about political matters. The freedom is an indispensable part of the requirement in sections 7 and 24 of the Constitution that the members of the Federal Parliament must be 'directly chosen by the people'.

The implied freedom takes precedence over statute and common law, and so is the most powerful form of legal authority. If it can be shown that the freedom applies, it trumps everything else. The freedom can also be used in a less direct sense in assisting courts with the development of the common law. For example, in the area of defamation law it has been used by the High Court to help shape the common law in regard to the defences that are appropriate in dealing with speech about political figures. ${ }^{9}$

\footnotetext{
${ }^{5}$ Aid/Watch Inc v Commission of Taxation (2010) 272 ALR 417 at 427.

${ }^{6}$ George Williams, A Charter of Rights for Australia (UNSW Press, 2007).

${ }^{7}$ (1992) 177 CLR 1.

8 (1992) 177 CLR 106.

${ }^{9}$ Lange v Australian Broadcasting Commission (1997) 189 CLR 520.
} 
The implied freedom may be powerful, but it has been rarely used. It has often been narrowly construed and judges have tended to be reluctant to apply it in other contexts, such as in the development of the common law. It was surprising then to see the freedom used as it was in the Aid/Watch Case.

It was recognised in the Aid/Watch Case that Aid/Watch is a self-described 'activist' group concerned with the relief of international poverty. The organisation seeks to achieve its goals through unorthodox means for a charity. Rather than raising money for or engaging directly in anti-poverty initiatives, it campaigns for improvements in the delivery of Australia's overseas aid. It has been sharply critical of government, and has not been shy in proposing major reforms to Australian aid policy.

The primary question was whether the public advocacy of Aid/Watch could permit the entity to fall within the fourth category of the definition of a charity: that is, could it be classed as a body concerned with 'other purposes beneficial to the community'. A majority of the High Court held that Aid/Watch did fit within this definition. The judges were fortified in this conclusion by the Australian Constitution and the implied freedom of political communication. In this respect, the joint majority judgment of Chief Justice French and Justices Gummow, Hayne, Crennan and Bell reasoned in the following steps: ${ }^{10}$

1. The foundation of the Australia's system of law is supplied by the Constitution.

2. The provisions of the Constitution mandate a system of representative and responsible government with a universal adult franchise, including a system for amendment of the Constitution in which the proposed law to effect the amendment is to be submitted to the electors.

3. Communication between electors and legislators and the officers of the executive, and between electors themselves, on matters of government and politics is 'an indispensable incident' of that constitutional system.

4. Thus, the system of law which applies in Australia postulates for its operation 'agitation' for legislative and political changes.

5. While personal rights of action are not by these means bestowed upon individuals, the Constitution informs the development of the common law.

6. In this case, the common law should develop so as to recognise that bodies can both possess charitable status and 'agitate' for legislative and political changes.

${ }^{10}$ Aid/Watch Inc v Commission of Taxation (2010) 272 ALR 417 at 428-429. 
The majority concluded:

The system of law which applies in Australia thus postulates for its operation ... 'agitation' for legislative and political changes ... [I]t is the operation of these constitutional processes which contributes to the public welfare. A court administering a charitable trust for that purpose is not called upon to adjudicate the merits of any particular course of legislative or executive action or inaction which is the subject of advocacy or disputation within those processes.

Tucked away towards the end of the majority judgment, this reasoning may well have proved decisive. The recognition of political 'agitation' as a source of protected communication informed the development of the common law such that the political 'agitation' could be seen as being for the public welfare. The result was that 'in Australia there is no general doctrine which excludes from charitable purposes "political objects", ${ }^{11}$ and thus that charitable status is not inconsistent with freedom of speech by non-government organisations about matters of government and public policy. In the specific case of Aid/Watch, the majority held that the 'generation by lawful means of public debate ... concerning the efficiency of foreign aid directed to the relief of poverty ... is a purpose beneficial to the community within the fourth head in Pemsel', ${ }^{12}$

\section{Implications}

The Aid/Watch Case demonstrates how the Constitution and implications drawn from it can exert a powerful influence on the law in other areas. All such law must ultimately be referable to the Constitution, and the Constitution can play a major role in its development. In Aid/Watch, it was significant that the implied freedom was used in a case not about the rights of electors, but those of a non-government organisation.

It was an extension to take freedom from its electoral context as provided by sections 7 and 24 of the Constitution into the charitable realm. Indeed, it may well be that the Constitution can play a like role in other areas where the non-government sector seeks protection or recognition of its role in engaging in political debate. Should a statute seek to close down public advocacy or 'agitation’ for legislative and political changes by such organisations, there may be good grounds to argue that this breaches the Constitution.

\footnotetext{
${ }^{11}$ Aid/Watch Inc v Commission of Taxation (2010) 272 ALR 417 at 429.

${ }^{12}$ Aid/Watch Inc v Commission of Taxation (2010) 272 ALR 417 at 429.
} 
The use of the Constitution in the Aid/Watch Case also suggests paths for the future development of what it means to be a 'charitable institution'. First, the use of the Constitution implies limits upon the power of Australian parliaments to narrow the definition of what it means to be a charity, such as by seeking to legislate to exclude bodies engaged in political activities from that definition.

The Aid/Watch Case was an interpretation of federal tax legislation in light of the common law definition of what it means to be a charity. This would normally mean that Parliament can change that legislation so as to narrow the definition. However, the High Court's reliance upon the Constitution may prove to be a barrier. If the definition of a charity was altered to prevent bodies from engaging in public debate about matters of government and public policy, this could run foul of the constitutional freedom of political communication and be struck down ${ }^{13}$. Such considerations also apply in the event of an Australian parliament seeking to enact a new, comprehensive definition of charities for taxation or other laws. ${ }^{14}$ Any such definition must also comply with the implied freedom of political communication.

Second, the Constitution may assist with resolving questions left after the Aid/Watch Case about whether other bodies engaged in political activities can be classed as a 'charitable institution'. These questions might be answered by the courts in an open-ended way purely by reference to the common law, but it is possible that the Constitution may be again used.

In so far as the Constitution is applied, it would support the protection, and thus the classification as a 'beneficial purpose', of 'agitation' directed at matters such as the criticism of government policy and attempts to change the law. Such matters lie at the heart of the implied freedom of political communication because they go to the discussion of matters that affect the choice made by electors under sections 7 and 24 of the Constitution. The High Court did not set out in detail what it means by 'agitation' in this context, but it would seem clear that it extends to matters such as the publication of critical comment or the provocation of public debate with a view to generating support for legal and policy change.

\footnotetext{
${ }^{13}$ For analogous reasoning, see Lange v Australian Broadcasting Commission (1997) 189 CLR 520.

${ }^{14}$ See generally I F Sheppard, Robert Fitzgerald and David Gonski, Report of the Inquiry into the Definition of Charities and Related Organisations (June 2001).
} 
The use of the Constitution in this way may also suggest to a court restrictions upon which bodies may be recognised as a charity. This limited form of protected 'agitation' was made clear by the fact that in describing 'agitation' as something in which a charity may engage, the majority of the High Court was careful to only ever use the phrase “"agitation”” for legislative and political changes'. This reflects the limited scope of the constitutional freedom. The implied freedom only extends to protection of 'agitation' relating to political matters that affect the choice of electors at the ballot box. It does not relate to other forms of speech, such as matters of artistic freedom or commercial speech that do not have a electoral/political element.

For example, it may be that bodies that advocate change directed at purely corporate interests (perhaps criticism of the overseas operations of Australian business interests) would not fall under the umbrella of constitutional protection, and thus charitable status. More generally, bodies which criticise or engage in advocacy about matters outside of the parliamentary and governmental realm, such as in regard to the medical profession or medical research, would not gain the protection of the Constitution and so may not be recognised as being charitable. Again, it must be remembered that the High Court majority did not speak about 'agitation' in general as being protected by the Constitution, but only “'agitation” for legislative and political change'. ${ }^{15}$

\section{Conclusion}

The Aid/Watch Case represents a good outcome for Australian democracy. It means that a range of charitable organisations can take part in public debate with greater freedom and confidence. These and other bodies promise to make an important contribution. Organisations dedicated to fighting poverty will be able to criticise governments where federal and State policies are inadequate in areas like dental care, mental health and homelessness. In these and other areas, such bodies can contribute a longer term, non-party political perspective on what needs to be done to remedy major problems and policy challenges. These bodies should not be muzzled by the threat that playing such a public role could threaten their status as a charity.

The fact that the Constitution underpinned this result is of undoubted significance. It implies a level of protection for such organisations that puts 'agitation' by them for legislative and

\footnotetext{
${ }^{15}$ Aid/Watch Inc v Commission of Taxation (2010) 272 ALR 417 at 429.
} 
political change beyond the scope of parliamentary override. The use of the Constitution also represents recognition by the High Court of the value of the public activities of these nongovernment organisations. It suggests a broadly conceived civil society in which robust advocacy and criticism of government laws and policies is something that is protected under the name of ensuring that the Australian public can cast an informed vote at the ballot box. 